\title{
Anthropometric parameters as predictors of muscle mass in el- derly women
}

\section{Parâmetros antropométricos como preditores da massa muscular em mu- Iheres idosas}

\author{
Fábio da Silva Santana1, Breno Quintela Farah², Antonio Henrique Germano Soares², \\ Marilia de Almeida Correia², Thaliane Mayara Pessôa dos Prazeres², Ademar Lucena Fi- \\ Iho², Raphael Mendes Ritti-Dias ${ }^{1,2,3 *}$
}

ARTIGO ORIGINAL | ORIGINAL ARTICLE

\begin{abstract}
The aims of study were to analyze the relationship between muscle mass and anthropometric parameters in elderly women and to develop a mathematical model to predict muscle mass based on anthropometric parameters. The study included 63 elderly women (71.4 \pm 4.4 years). Body weight, height, arm, waist, hip and calf circumferences were measured. Muscle mass was estimated using a densitometry. The muscle mass index was calculated using the equation (muscle mass index $=$ muscle mass $[\mathrm{kg}] /$ height $[\mathrm{m}]^{2}$ ). A significant correlation was found between muscle mass and body weight $(r=0.782)$, arm $(r=0.688)$, waist $(r=0.467)$, hip $(r=0.629)$ and calf circumferences $(r=0.592)$ with $p<0.05$ for all. Regression analysis indicated that body mass and calf circumference were independent predictors of muscle mass $\left(\mathrm{r}=0.81, \mathrm{r}^{2}=0.65, \mathrm{~F}=55.7\right)$. The prediction model obtained was muscle mass $(\mathrm{kg})=-0.543+(0.162 \times$ body mass $)+(0.151 \times$ calf circumference $)$. No differences were observed between the amount of muscle mass and muscle mass index estimated by densitometry and by equation $(p>0.05)$. The results of this study indicated that body mass, body mass index, arm, waist, hip and calf circumferences are related to muscle mass elderly women. The muscle mass can be adequately predicted based on data from body mass and calf circumference.
\end{abstract}

Keywords: aging, elderly, body composition, skeletal muscle

RESUMO

Os objetivos do estudo foram analisar a relação entre a massa muscular e parâmetros antropométricos em mulheres idosas e desenvolver um modelo matemático para predição da massa muscular. O estudo incluiu 63 idosas $(71 \pm 4.4$ anos). Massa corporal, altura e circunferências do braço, cintura, quadril e panturrilha foram medidas. Massa muscular foi estimada utilizando a densitometria. $O$ índice de massa muscular foi calculado usando a equação (índice de massa muscular= massa muscular [kg] / altura $\left.[\mathrm{m}]^{2}\right)$. Uma correlação significante foi encontrada entre a massa muscular e a massa corporal $(\mathrm{r}=0.782)$, circunferência do braço $(r=0.688)$, circunferência da cintura $(r=0.467)$, circunferência do quadril ( $r$ $=0.629)$ e circunferência da panturrilha $(\mathrm{r}=0.592)$ com $\mathrm{p}<0.05$ para todas. A análise de regressão indicou que a massa corporal e a circunferência da panturrilha foram preditores independentes da massa muscular $\left(\mathrm{r}=0.81, \mathrm{r}^{2}=0.65, \mathrm{~F}=55.7\right)$. O modelo de regressão linear obtido foi de massa muscular $(\mathrm{kg})=-0.543+(0.162 \times$ massa corporal $)+(0.151 \times$ circunferência da panturrilha $)$. Não foram observadas diferenças entre a massa muscular e o índice de massa muscular estimados pela densitometria e pela equação $(p>0.05)$. Os resultados deste estudo indicaram que a massa corporal, índice de massa corporal, circunferência do braço, circunferência da cintura, circunferência do quadril e circunferência da panturrilha estão relacionados com a massa muscular de mulheres idosas. A massa muscular pode ser adequadamente predita com base nos dados de massa corporal e de circunferência da panturrilha. Palavras-chaves: envelhecimento, idosos, composição corporal, músculo-esquelético

\footnotetext{
Manuscript received March 27, 2014; Accepted October $24^{\text {th }}, 2014$

${ }^{1}$ Program of Post-Graduation in Hebiatria of University of Pernambuco, Recife, Brazil

${ }^{2}$ Associated Program of Post-Graduation of University of Pernambuco and Federal University of Paraíba, Recife/João Pessoa, Brazil

${ }^{3}$ Albert Einstein Institute of Education and Research, São Paulo, Brazil

* Autor correspondente: Escola Superior de Educação Física, Universidade de Pernambuco, Rua Arnóbio Marques, 310. Santo Amaro, Recife, PE, CEP: 50100-130, Brasil E-mail: raphaelritti@gmail.com
} 


\section{INTRODUCTION}

The ageing process alters body composition, including increases in adiposity and decreases in muscle mass (MM) (Baumgartner, 2000; Baumgartner, Waters, Gallagher, Morley, \& Garry, 1999; Doherty, 2003; Forbes \& Reina, 1970; Lang et al., 2010). Reduction in MM due to ageing is one of the most important factors, since it directly impacts the functionality of elderly (Baumgartner et al., 1998; Janssen, 2006), by reducing muscular strength and power (Deschenes, 2004), this condition is commonly called sarcopenia. The more pronounced changes occur in women, especially after menopause and constitute a major public health problem (Janssen, Heymsfield, \& Ross, 2002).

Sarcopenia have been identified in the elderly using the MM index (MMI) (Janssen et al., 2002; Rech, Dellagrana, Marucci, \& Petroski, 2012; Rolland et al., 2003), which is closely related to muscle fitness, functional impairment and disability (Janssen et al., 2002). Therefore, the early identification of sarcopenia can improve the therapeutic strategies in order to prevent the decreases MM reduction. However, obtaining of MMI requires expensive equipment (Janssen et al., 2002; Tichet et al., 2008), limiting its use in clinical practice. Thus, more affordable methods for estimating MM in the elderly are needed.

Anthropometry has been used to estimate MM in men, women, healthy, malnourished overweight and obese individuals (Baumgartner et al., 1998; Baumgartner et al., 1999; Chumlea, Guo, Vellas, \& Guigoz, 1995; Patrick, Bassey, \& Fentem, 1982; Quiroz-Olguin, Serralde-Zuniga, Saldana-Morales, \& Guevara-Cruz, 2013). McIntosh et al (2013) recently developed an equation to estimate the MMI in the elderly; however, the equation was proposed using bioelectrical impedance as the standard method and this is known to produce a significant bias in the estimation of MM (Williams \& Bale, 1998). Furthermore, this study did not analyze the concordance between measures, which sets up an important gap about quality of the proposed model (Williams \& Bale, 1998).
In this sense, although the method dual-energy X-ray absorptiometry (DXA) is not the gold standard for body composition assessments, some evidence showed that it provides more accurate values when compared to bioelectrical impedance, which suggest that the use of mathematical models based on the DXA parameters to estimate the MM appears to be more reliable than bioelectrical impedance.

Therefore, the aims of study were to analyze the relationship between muscle mass and anthropometric parameters in elderly women and to develop a mathematical model to predict muscle mass based on anthropometric parameters.

\section{Participants}

Were recruited 63 recreationally active elderly women, involved in exercise program at the University, this program consisted basically of water aerobics. Inclusion criteria were age greater than or equal to 65 years old and attended by physical activity program at the University. Volunteers with disabilities, inability to perform the measurement of DXA due diseases or refuse to make any anthropometric measure were excluded.

All participants were informed of the study procedures and signed a term of informed consent. The project was approved by the University's Research Ethics Committee (094/11).

\section{Procedures}

\section{Anthropometric parameters}

Body mass was measured with participants wearing light clothes and no shoes, using automatic scales (Welmy, São Paulo, Brazil), and height using a stadiometer connected to scales. Body mass index was calculated as the ratio between body mass and height squared. The criterion used for obesity was a body mass index of $30 / \mathrm{kg} / \mathrm{m}^{2}$ or higher. The circumferences of the right arm, waist, hip and calf were assessed using a flexible measuring tape (Sanny, São Paulo, Brazil). All circumferences were obtained in triplicate, according to the standard procedure 
proposed by Callaway et al (1988), by the same evaluator certificate by International Society for Advancement in Kinanthropometry (ISAK).

\section{Body composition}

MM was estimated by DXA (Lunar Prodigy DXA, model NRL 41990, GE Lunar, Madison, WI). For the assessment, participants were instructed to remain clothed but to remove any metallic prosthesis or objects. The procedure lasted 5 to 10 minutes for each individual and was carried out by the same technician who calibrated the device according to the manufacturer's recommendations. The values of fat free mass in the appendicular area were used to estimate muscle mass (Kim, Wang, Heymsfield, Baumgartner, \& Gallagher, 2002). The MMI was calculated as $\left[\mathrm{MM}(\mathrm{kg}) \div\right.$ height $\left.(\mathrm{m})^{2}\right]$ (Lee et al., 2000).

\section{Statistical analysis}

Data normality was confirmed using the Kolmogorov-Smirnov test. Pearson's coefficient correlation was used to confirm the relationship between MM and anthropometric parameters.
Simple and multiple linear regression models were performed to assess the predictive value of variables (age, body mass, height, body mass index, arm waist, hip, calf circumferences) and estimate MM. Based on this analysis, a mathematical equation was proposed to estimate MM. The MM and MMI values obtained by DXA were compared with the estimated values obtained from the proposed regression model using the paired t-test. Bland-Altman (1986) plots were used to check the consistency between the values obtained using DXA and those estimated by the equation and to describe the average difference (bias) and the respective limits of agreement.

For all inferential analysis the significance level adopted was $5 \%$. The procedures were carried out using the Statistical Package for the Social Sciences, version 20 and GraphPad Prism version 6.0.

\section{RESULTS}

The characteristics of the sample are presented in table 1.

Table 1

General characteristics of the sample $(n=63)$

\begin{tabular}{lc}
\hline Variables & Values \\
\hline Age (years) & $71.4 \pm 4.4$ \\
Body mass $(\mathrm{kg})$ & $70.6 \pm 12.1$ \\
Height $(\mathrm{m})$ & $1.54 \pm 0.06$ \\
Body mass index $\left(\mathrm{kg} / \mathrm{m}^{2}\right)$ & $29.8 \pm 4.8$ \\
Prevalence of obesity $(\%)$ & 39.7 \\
Muscle mass $(\mathrm{kg})$ & $17.6 \pm 3.1$ \\
Muscle mass index $\left(\mathrm{kg} / \mathrm{m}^{2}\right)$ & $7.4 \pm 1.2$ \\
Fat mass $(\%)$ & $46.9 \pm 4.7$ \\
Fat mass $(\mathrm{kg})$ & $57.3 \pm 8.4$ \\
Fat free mass $(\%)$ & $21.41 \pm 2.9$ \\
Fat free mass $(\mathrm{kg})$ & $15.3 \pm 4.1$ \\
Right arm circumference $(\mathrm{cm})$ & $31.5 \pm 3.7$ \\
Waist circumference $(\mathrm{cm})$ & $94.5 \pm 10.7$ \\
Hip circumference $(\mathrm{cm})$ & $106.2 \pm 10.0$ \\
Calf circumference $(\mathrm{cm})$ & $36.3 \pm 4.7$ \\
\hline
\end{tabular}

The data are presented on mean and standard deviation. 
Table 2

Correlation between muscle mass and anthropometric parameters

\begin{tabular}{lcc}
\hline Muscle mass $(\mathrm{kg})$ & $\mathbf{r}$ & $\boldsymbol{P}$ \\
\hline Body mass $(\mathrm{kg})$ & 0.782 & $<0.001$ \\
Body mass index $\left(\mathrm{kg} / \mathrm{m}^{2}\right)$ & 0.737 & $<0.001$ \\
Right arm circumference $(\mathrm{cm})$ & 0.688 & $<0.001$ \\
Waist circumference $(\mathrm{cm})$ & 0.467 & $<0.001$ \\
Hip circumference $(\mathrm{cm})$ & 0.629 & $<0.001$ \\
Calf circumference $(\mathrm{cm})$ & 0.592 & $<0.001$ \\
\hline
\end{tabular}

Table 2 shows correlations between MM and anthropometric parameters. A significant positive correlation between MM and body mass, body mass index, arm circumference, waist circumference, hip circumference and calf circumference were observed $(p<0.001$ for all).
In multiple regression analysis, body mass $(\mathrm{F}=96.0)$ and calf circumference $(\mathrm{F}=32.9)$ adequately estimated $\mathrm{MM} \quad(\mathrm{F}=55.7 ; \mathrm{r}=0.81$; $\mathrm{r}^{2}=0.65$; SEE $\left.=1.83\right)$ (Table 3).

Table 3

Prediction model of muscle mass in elderly women.

\begin{tabular}{cccc}
\hline Variable & Model of prediction & $\mathbf{r}\left(\mathbf{R}^{2}\right)$ & $\mathrm{SEE}$ \\
\hline $\mathrm{MM}(\mathrm{kg})$ & $=-0.543+(0.162 *$ body mass $)+\left(0.151^{*}\right.$ calf circumference $)$ & $0.81(0.65)$ & 1.83 \\
\hline
\end{tabular}

$\mathrm{MM}=$ muscle mass; $\mathrm{r}=$ coefficient of multiple correlation; $\mathrm{R}^{2}=$ variation; $\mathrm{SEE}=$ standard error of estimate.

Figure 2 presents the agreement between MM and MMI values obtained by DXA and estimated by the proposed equation. The concordance between MM values estimated by proposed equation and obtained by DXA were: bias= 0.04 and $\mathrm{SD}=1.80$ and limits of agreement of
$95 \%$ for $(-3.60 ; 3.48)$. The concordance between MMI values estimated by proposed equation and obtained by DXA were bias $=0.16$ and $\mathrm{SD}=$ 0.73 and limits of agreement of $95 \%$ for $(-1.60$; 1.28).
A

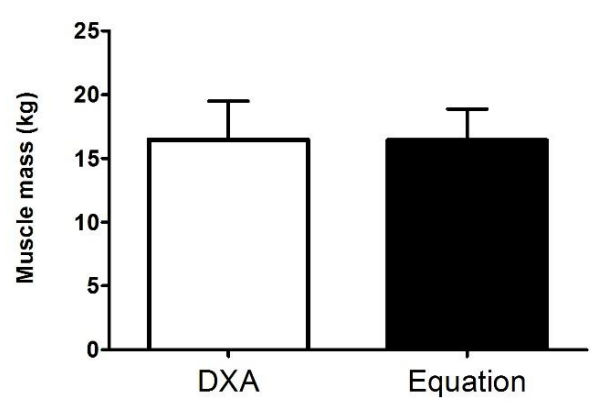

B

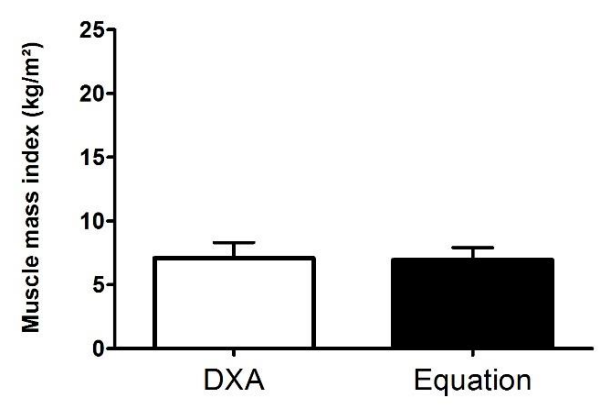

Figure 1. Values of muscle mass (Panel A) and muscle mass index (Panel B) obtained by DXA and estimated by equation in elderly $(n=63)$. 

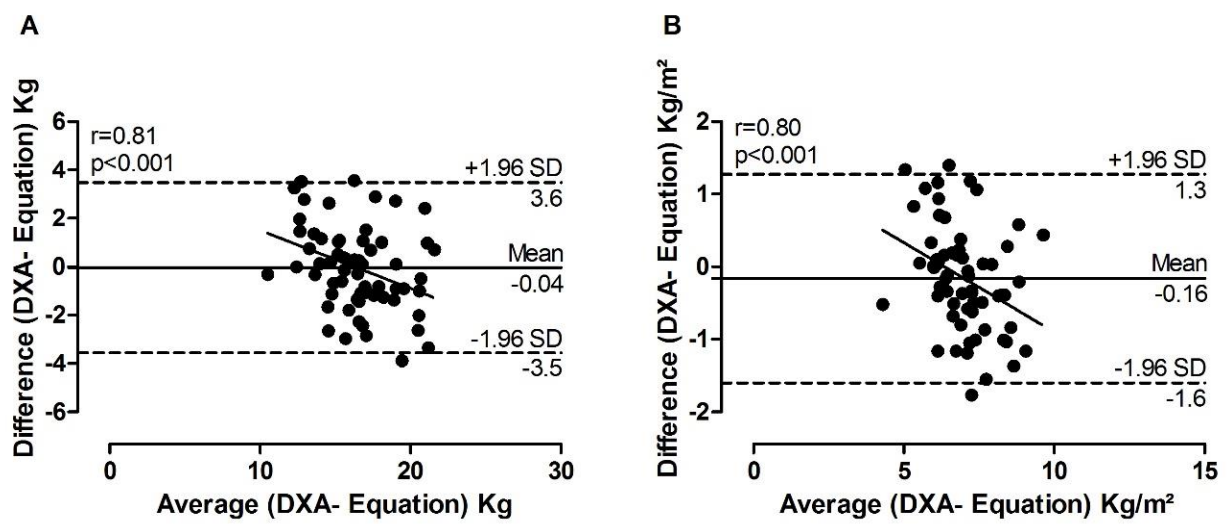

Figure 2. Correlation between the values of muscle mass ( $\mathrm{kg}$ ) (Panel A) and muscle mass index (Panel B) obtained by DXA and the values estimated by equation respectively. The dotted lines represent the $95 \%$ confidence interval. The continuous line represents the average standard error.

\section{DISCUSSION}

The novel findings of the present study were that: a) in elderly women, anthropometric parameters are positively associated with $\mathrm{MM} ; \mathrm{b}$ ) the proposed equation based on calf circumference and body weight adequately estimated MM.

In the present study, the body mass was the main predictor of MM in the elderly women. This finding is reasonable since the weight loss is one of the main health problems observed in this population (Kyle, Genton, \& Pichard, 2005; Kyle, Pirlich, Lochs, Schuetz, \& Pichard, 2005), affecting the immune system and cognitive functions, and this is a risk factor for infections, falls, and impairment of hepatic protein synthesis (Raslan et al., 2008). Furthermore, reductions in body weight during ageing are also associated with chronic diseases such as cancer (Wigmore, Plester, Richardson, \& Fearon, 1997), peripheral artery disease (McDermott et al., 2004), heart failure (Mancini et al., 1992), other disorders (Cesari \& Pahor, 2008) and in more advanced cases, can lead to cachexia (Argiles et al., 2010; Evans, 2010; Morley, Thomas, \& Wilson, 2006). On the order hand, the increment of body weight during aging has been associated with improved functionality (Harris, Ballard-Barbasch, Madans, Makuc, \& Feldman, 1993; Harris et al., 1997; Newman et al., 2005). In this study, there was an increase of $0.2 \mathrm{~kg}$ of MM per $1 \mathrm{~kg}$ of body weight, which highlights its importance for MM estimation. Therefore, maintenance of body weight in elderly women appears to be an important strategy to keep the MM.

Interestingly, in the present study, the circumferences related to adiposity (waist and hip) were associated with MM. These results may be, at least in part, explained by the elevated skeletal muscle workload in subjects with higher adiposity levels, which are in line with previous studies. In fact, Kuk et al (2007) showed a statistically significant relationship between hip circumference and thigh circumferences, as well as between lower-body and abdominal MM, regardless of waist circumference. Likewise, Baumgartner et al (1999) observed that obese elderly women may be protected from sarcopenia and this may in part be explained by the trophic effects of increased weight bearing on muscle. Regarding the circumferences examined in this study, those from the arm and calf were most strongly associated with MM, which is probably mediated by the lower adiposity observed in the limbs compared with trunk, making $\mathrm{MM}$ the primary component of these circumferences.

Likewise, the present study showed that the total MM was adequately estimated by body mass and calf circumference, using DXA as the 
reference method. Importantly, these anthropometric measurements are simple and easy to perform in practical situations by clinicians and health professionals, optimizing the planning and implementation of interventions in order to diagnose and prevent sarcopenia. These results are in line with previous studies in the literature (Doupe, Martin, Searle, Kriellaars, \& Giesbrecht, 1997; Martin, Spenst, Drinkwater, \& Clarys, 1990) that also have identified the potential of simple measures to estimate the MM. Martin et al (1990) and Doupe et al (1997) have reported high determination coefficients with equations based on cadaver dissection $\left(r^{2}=0.97\right.$ and $r^{2}=0.96$, respectively). Lee et al (2000) validated an equation to estimate MM by means of anthropometric parameters in obese and non-obese patients aged 20 to 80 and observed a high determination coefficient $\left(r^{2}=0.86\right)$. More recently, Pereira et al. (2013) assessed 264 women aged 60 to 84 years and adequately estimated appendicular muscle mass using various equations based on anthropometric measures such as body mass, body mass index, thigh skinfold and thigh, hip and forearm circumferences $\left(r^{2} \geq 0.70\right.$ for all equations). Likewise, the present study was able to adequately estimate the total MM, using body mass and calf circumference, using DXA as the reference method. These anthropometric measures are simple and easy to perform in some research situations and/or in evaluations of body composition at non-laboratory conditions with the purpose of reducing exposure of body parts.

These results have important practical applications, since it is possible to estimate the MMI, which is widely used for diagnosis of sarcopenia, without incurring high costs in non-laboratory environments. Early identification of sarcopenia may lead to interventions to reduce the impact of this important women's health issue. However, despite the good fit obtained using the proposed equation there was a significant correlation between the mean of the differences and the average MM in the Bland-Altman analysis. These results indicate that the proposed equation underestimates the MM in elderly people with higher MM and overestimates it in those with lower MM. In practical terms, MM over estimation in elderly women with lower MM may limit the identification of sarcopenia. In fact, based on the criteria proposed by Janssen et al (2004) only one elderly woman presented with sarcopenia when MM was estimated using an anthropometric equation, while DXA identified four participants with sarcopenia. These results suggest that caution should be taken in elderly women with low MM, even if they do not meet the criteria for sarcopenia.

The present study has a number of limitations. First, the sample size calculation was not performed previously. Second, MM was estimated using DXA and not magnetic resonance imaging, although DXA is not the gold standard for estimating MM (Lee, Wang, \& Heymsfield, 2001). Third, the proposed equation for MM estimation was not cross-validated in an independent group of elderly women. Finally, this study was performed in elderly women and caution should be taken in extrapolating the results for other populations.

\section{CONCLUSION}

In conclusion, the results of the present study indicate that $\mathrm{MM}$ is related to anthropometric parameters and that the linear regression model proposed can adequately predict MM in elderly women.

\section{Agradecimentos:}

Nothing to declare

Conflito de Interesses:

Nothing to declare

Financiamento:

Nothing to declare 


\section{REFERÊNCIAS}

Argiles, J. M., Anker, S. D., Evans, W. J., Morley, J. E., Fearon, K. C., Strasser, F., . . Baracos, V. E. (2010). Consensus on cachexia definitions. Journal of the American Medical Directors Association, 11(4), 229-230. doi: 10.1016/j.jamda.2010.02.004

Baumgartner, R. N. (2000). Body composition in healthy aging. Annals of the New York Academy of Sciences, 904, 437-448.

Baumgartner, R. N., Koehler, K. M., Gallagher, D., Romero, L., Heymsfield, S. B., Ross, R. R., . . . Lindeman, R. D. (1998). Epidemiology of sarcopenia among the elderly in New Mexico. American Journal of Epidemiology, 147(8), 755763.

Baumgartner, R. N., Waters, D. L., Gallagher, D., Morley, J. E., \& Garry, P. J. (1999). Predictors of skeletal muscle mass in elderly men and women. Mechanisms of Ageing and Development, 107(2), 123-136.

Bland, J. M., \& Altman, D. G. (1986). Statistical methods for assessing agreement between two methods of clinical measurement. The Lancet, 1(8476), 307-310.

Callaway, C., Chumlea, W., Bouchard, C., Himes, J., Lohman, T., Martin, A., . . Seefeldt, V. (1988). Circunferences. Anthropometric standardization reference manual, 39-54.

Cesari, M., \& Pahor, M. (2008). Target population for clinical trials on sarcopenia. The Journal of Nutrition Health and Aging, 12(7), 470-478.

Chumlea, W. C., Guo, S. S., Vellas, B., \& Guigoz, Y. (1995). Techniques of assessing muscle mass and function (sarcopenia) for epidemiological studies of the elderly. The journals of gerontology. Series A, Biological sciences and medical sciences, 50 Spec No, 45-51.

Deschenes, M. R. (2004). Effects of aging on muscle fibre type and size. Sports Medicine, 34(12), 809824.

Doherty, T. J. (2003). Invited review: Aging and sarcopenia. Journal of applied physiology, 95(4), $1717-1727$.

doi: 10.1152/japplphysiol.00347.2003

Doupe, M. B., Martin, A. D., Searle, M. S., Kriellaars, D. J., \& Giesbrecht, G. G. (1997). A new formula for population-based estimation of whole body muscle mass in males. Canadian Journal of Applied Physiology, 22 (6), 598-608.

Evans, W. J. (2010). Skeletal muscle loss: cachexia, sarcopenia, and inactivity. The American Journal of Clinical Nutrition, 91(4), 1123S-1127S. doi: 10.3945/ajen.2010.28608A

Forbes, G. B., \& Reina, J. C. (1970). Adult lean body mass declines with age: some longitudinal observations. Metabolism, 19(9), 653-663.

Harris, T. B., Ballard-Barbasch, R., Madans, J., Makuc, D. M., \& Feldman, J. J. (1993). Overweight, weight loss, and risk of coronary heart disease in older women. The NHANES I Epidemiologic Follow-up Study. American Journal of Epidemiology, 137(12), 1318-1327.

Harris, T. B., Savage, P. J., Tell, G. S., Haan, M., Kumanyika, S., \& Lynch, J. C. (1997). Carrying the burden of cardiovascular risk in old age: associations of weight and weight change with prevalent cardiovascular disease, risk factors, and health status in the Cardiovascular Health Study. The American Journal of Clinical Nutrition, 66(4), 837-844.

Janssen, I. (2006). Influence of sarcopenia on the development of physical disability: the Cardiovascular Health Study. Journal of the American Geriatrics Society, 54(1), 56-62. doi: 10.1111/j.1532-5415.2005.00540.x

Janssen, I., Baumgartner, R. N., Ross, R., Rosenberg, I. H., \& Roubenoff, R. (2004). Skeletal muscle cutpoints associated with elevated physical disability risk in older men and women. American Journal of Epidemiology, 159(4), 413421.

Janssen, I., Heymsfield, S. B., \& Ross, R. (2002). Low relative skeletal muscle mass (sarcopenia) in older persons is associated with functional impairment and physical disability. Journal of the American Geriatrics Society, 50(5), 889-896.

Kim, J., Wang, Z., Heymsfield, S. B., Baumgartner, R. N., \& Gallagher, D. (2002). Total-body skeletal muscle mass: estimation by a new dual-energy X-ray absorptiometry method. The American Journal of Clinical Nutrition, 76(2), 378-383.

Kuk, J. L., Janiszewski, P. M., \& Ross, R. (2007). Body mass index and hip and thigh circumferences are negatively associated with visceral adipose tissue after control for waist circumference. The American Journal of Clinical Nutrition, 85(6), 1540-1544.

Kyle, U. G., Genton, L., \& Pichard, C. (2005). Hospital length of stay and nutritional status. Current Opinion in Clinical Nutrition \& Metabolic Care, 8(4), 397-402.

Kyle, U. G., Pirlich, M., Lochs, H., Schuetz, T., \& Pichard, C. (2005). Increased length of hospital stay in underweight and overweight patients at hospital admission: a controlled population study. Clinical Nutrition, 24(1), 133-142. doi: 10.1016/j.clnu.2004.08.012

Lang, T., Streeper, T., Cawthon, P., Baldwin, K., Taaffe, D. R., \& Harris, T. B. (2010). Sarcopenia: etiology, clinical consequences, intervention, and assessment. Osteoporosis International, 21(4), 543-559. doi: 10.1007/s00198-009-1059-y

Lee, R. C., Wang, Z., Heo, M., Ross, R., Janssen, I., \& Heymsfield, S. B. (2000). Total-body skeletal muscle mass: development and cross-validation of anthropometric prediction models. The American Journal of Clinical Nutrition, 72(3), 796803. 
Lee, R. C., Wang, Z. M., \& Heymsfield, S. B. (2001). Skeletal muscle mass and aging: regional and whole-body measurement methods. Canadian Journal of Applied Physiology, 26(1), 102-122.

Mancini, D. M., Walter, G., Reichek, N., Lenkinski, R., McCully, K. K., Mullen, J. L., \& Wilson, J. R. (1992). Contribution of skeletal muscle atrophy to exercise intolerance and altered muscle metabolism in heart failure. Circulation, 85(4), 1364-1373. doi: 10.1161/01.cir.85.4.1364

Martin, A. D., Spenst, L. F., Drinkwater, D. T., \& Clarys, J. P. (1990). Anthropometric estimation of muscle mass in men. Medicine $\mathcal{E}$ Science in Sports \& Exercise, 22(5), 729-733.

McDermott, M. M., Guralnik, J. M., Albay, M., Bandinelli, S., Miniati, B., \& Ferrucci, L. (2004). Impairments of muscles and nerves associated with peripheral arterial disease and their relationship with lower extremity functioning: the InCHIANTI Study. Journal of the American Geriatrics Society, 52(3), 405-410.

McIntosh, E. I., Smale, K. B., \& Vallis, L. A. (2013). Predicting fat-free mass index and sarcopenia: A pilot study in community-dwelling older adults. Age, 35(6), 2423-2434. doi: 10.1007/s11357012-9505-8

Morley, J. E., Thomas, D. R., \& Wilson, M. M. (2006). Cachexia: pathophysiology and clinical relevance. The American Journal of Clinical Nutrition, 83(4), 735-743.

Newman, A. B., Lee, J. S., Visser, M., Goodpaster, B. H., Kritchevsky, S. B., Tylavsky, F. A., . . . Harris, T. B. (2005). Weight change and the conservation of lean mass in old age: the Health, Aging and Body Composition Study. The American Journal of Clinical Nutrition, 82 (4), 872878; quiz 915-876.

Patrick, J. M., Bassey, E. J., \& Fentem, P. H. (1982). Changes in body fat and muscle in manual workers at and after retirement. European Journal of Applied Physiology and Occupational Physiology, 49(2), 187-196.

Pereira, P. G., da Silva, G. A., Santos, G. M., Jr., Petroski, E. L., \& Geraldes, A. R. (2013).
Development and validation of anthropometric equations to estimate appendicular muscle mass in elderly women. Nutrition journal, 12(1), 92. doi: 10.1186/1475-2891-12-92

Quiroz-Olguin, G., Serralde-Zuniga, A. E., SaldanaMorales, V., \& Guevara-Cruz, M. (2013). Validation of a new formula for predicting body weight in a Mexican population with overweight and obesity. Nutrición Hospitalaria, 28(3), 690-693. doi: 10.3305/nh.2013.28.3.6455

Raslan, M., Gonzalez, M. C., Dias, M. C. G., PaesBarbosa, F. C., Cecconello, I., \& Waitzberg, D. L. (2008). Applicability of nutritional screening methods in hospitalized patients. Brazilian Journal of Nutrition, 21, 553-561.

Rech, C. R., Dellagrana, R. A., Marucci, M. d. F. N., \& Petroski, E. L. (2012). Validity of anthropometric equations for the estimation of muscle mass in the elderly. Brazilian Journal of Kinanthropometry and Human Performance, 14, 2331.

Rolland, Y., Lauwers-Cances, V., Cournot, M., Nourhashemi, F., Reynish, W., Riviere, D., . . . Grandjean, H. (2003). Sarcopenia, calf circumference, and physical function of elderly women: a cross-sectional study. Journal of the American Geriatrics Society, 51 (8), 1120-1124.

Tichet, J., Vol, S., Goxe, D., Salle, A., Berrut, G., \& Ritz, P. (2008). Prevalence of sarcopenia in the French senior population. The Journal of Nutrition Health and Aging, 12(3), 202-206.

Wigmore, S. J., Plester, C. E., Richardson, R. A., \& Fearon, K. C. (1997). Changes in nutritional status associated with unresectable pancreatic cancer. British Journal of Cancer, 75(1), 106-109.

Williams, C. A., \& Bale, P. (1998). Bias and limits of agreement between hydrodensitometry, bioelectrical impedance and skinfold calipers measures of percentage body fat. European Journal of Applied Physiology and Occupational Physiology, 277(3), 271-277. doi: $10.1007 / \mathrm{s} 004210050332$

Todo o conteúdo da revista Motricidade está licenciado sob a Creative Commons, exceto quando especificado em contrário e nos conteúdos retirados de outras fontes bibliográficas. 